\title{
CHEMICAL EQUILIBRIUM OF SOIL SOLUTION IN STEPPE ZONE SOIL
}

\author{
${ }^{1}$ Batukaev, A.A., ${ }^{2}$ A.P. Endovitsky, ${ }^{3}$ T.M. Minkina, \\ ${ }^{2}$ V.P. Kalinichenko, ${ }^{1}$ Z.S. Dikaev and ${ }^{3}$ S.N. Sushkova
}

\begin{abstract}
${ }^{1}$ The Chechen State University, 364907, Grozny, Sheripov St., 32, Chechen Republic, Russian Federation
${ }^{2}$ Institute of Fertility of Soils of South Russia, 346493, Persianovska, Rostov Region, Russian Federation

${ }^{3}$ Southern Federal University, 344006, Bolshaya Sadovaya St., 105, Rostov-on-Don, Russian Federation
\end{abstract}

Received 2014-05-29; Revised 2014-06-09; Accepted 2014-06-24

\begin{abstract}
Dynamics of material composition, migration and accumulation of salts is determined by chemical equilibrium in soil solution. Soil solution contains associated electrically neutral ion pairs $\mathrm{CaCO}_{3}{ }^{0} ; \mathrm{CaSO}_{4}{ }^{0}$, $\mathrm{MgCO}_{3}{ }^{0}, \mathrm{MgSO}_{4}{ }^{0}$, charged ion pairs $\mathrm{CaHCO}_{3}{ }^{+}, \mathrm{MgHCO}_{3}{ }^{+}, \mathrm{NaCO}_{3}^{-}, \mathrm{NaSO}_{4}{ }^{-}, \mathrm{CaOH}^{+}, \mathrm{MgOH}^{+}$. Calculation method is proposed for quantitative assessment of real ion forms in the soil solution of chestnut solonetz soil complex. Were proposed equations to calculate free and associated forms of ions. To solve the equations were used an iteration, a linear interpolation of equilibrium constants, a Method of Ionic Pairs including a law of initial concentration preservation, a law of the operating masses of equilibrium system, the concentration constants of ion pair dissociation on the law of operating masses. Was determined the quantity of ion free form and a coefficient of ion association as ratio of ions free form to analytical content $\gamma_{e}=C_{a s s} / C_{a n}$. The association of ions varies in individual soils and soil layer. Increasing soil solution salinity amplifies the ions association. In form of ionic pairs in soil solution are: $11.8-53.8 \%$ of $\mathrm{Ca}^{2+}$; 9.4-57.3\% of $\mathrm{Mg}^{2+} ; 0.7-11.9 \%$ of $\mathrm{Na}^{+} ; 2.2-22.3 \%$ of $\mathrm{HCO}_{3}^{-}, 11.8-62.7 \%$ of $\mathrm{SO}_{4}{ }^{2-}$. The ion $\mathrm{CO}_{3}{ }^{2-}$ is high associated, the share of ions in associated form is up to $92.7 \%$. The degree of soil solution saturation was obtained for three level of approximation accounting on analytical concentration, calculated association coefficient, calculated coefficient of association. Relating to thermodynamic solubility product $\mathrm{S}_{0}$, the mathematical product of analytical ionic pairs indicated super saturation of soil solutions up to $K_{1}=100$, taking into account calculated coefficient of association ion activity super saturation of soil solutions is absent, $K_{3} \approx 1$. Only for solonetz chestnut meadow $K_{3} \approx 2-5$. The soil solution saturation degree in soil profile and laterally in landscape varies. The quantitative assessment of real ion forms in the soil solution allows explain evolution of landscape of salted soils, structure of soil cover. Calculations fulfilled show that a possibility of soil degradation scenario taking into account the laws of association of ions in soil solution is much more probable and dangerous than it was assessed before. New understanding of water-salt transfer, geochemical barriers and ecological functions of soil will help to improve rainfed and irrigational agriculture.
\end{abstract}

Keywords: Soil Solution, Chemical Equilibrium, Ion Association, Calculation Method, Landscape, Structure of Soil Cover

\section{INTRODUCTION}

Soil solution-active part of the soil influencing its properties (Amakor et al., 2013; Endovitsky et al., 2014a; 2014b; Hunenberger and Reif, 2011; Visconti and De Paz, 2012; Opfergelt et al., 2014).

The chemical equilibrium in soil solution cause migration and accumulation of salts in soil, landscape

Corresponding Author: Batukaev, A.A., The Chechen State University, 364907, Grozny, Sheripov St., 32, Chechen Republic, Russian Federation 
and in different chemical systems (Endovitsky et al., 2014a; 2014b; Kar and Berenjian, 2013; Mary and Carol, 2014; Plugatyr et al., 2011). This balance plays an important role in the genesis and evolution of soil (Kalinichenko et al., 2011; 2012a; 2012b; 2014; Maiti and Rogers, 2011; Lui et al., 2011; Luo et al., 2013).

In soil solution are formed electrically neutral ion pairs $\mathrm{CaCO}_{3}{ }^{0} ; \mathrm{CaSO}_{4}{ }^{0}, \mathrm{MgCO}_{3}{ }^{0}, \mathrm{MgSO}_{4}{ }^{0}$, charged ion pairs $\mathrm{CaHCO}_{3}{ }^{+}, \mathrm{MgHCO}_{3}{ }^{+}, \mathrm{NaCO}_{3}^{-}, \mathrm{NaSO}_{4}^{-}, \mathrm{CaOH}^{+}$, $\mathrm{MgOH}^{+}$. Communications between associated ions are not as strong as in molecules, but diverse (Endovitsky et al., 2014a; 2014b; Hunenberger and Reif, 2011; Stoyanov et al., 2011; Raiteri et al., 2012; Dave and Dikshit, 2011; Zhang et al., 2012; Mandzhieva et al., 2014; Tertre et al., 2011).

In landscape the properties of soil solution are variable. Spatial heterogeneity of the Structure of Soil Cover (SSC) is caused by salinization of parent rock, low general moistening of soil, lateral differentiation of landscape, complexity of soil cover. The properties of landscape depend on thermodynamic equilibrium in soil solution of each element of SSC. The unity of these equilibria influences migration, accumulation of salts in soil continuum and causes the evolution of SSC. The knowledge of thermodynamic equilibria of soil solution is the fundamental base to find the ways of correct anthropogenous transformation of soil and landscape, ensure steady operated soil evolution, increase the soil fertility by method of Biogeo system technique (Kalinichenko et al., 2011; 2012a; 2012b; 2014).

\section{MATERIALS AND METHODS}

\subsection{Study Area}

The South-East of the Russian Federation, Rostov region. Lower Don.

Object of research. Key plot 1324-the dry steppe automorphic laterally differentiated complex of chestnet soils: Solonetz chestnut steppe, Chestnut solonetzic soil, Chestnut-dark soil of depression. Key plot 1325-the dry steppe hydromorphic complex of chestnut soils: Solonetz chestnut meadow.

The climate is arid, annual precipitation of 300-350 $\mathrm{mm}$. The parent rocks are Carbonate and Carbonatesulfate loess-like loam and clay (Kalinichenko et al., 2011; 2014).

\subsection{Sampling and Analysis of Soil}

Properties of investigated soils of chestnut soil complexes are laterally different, but in general of key plots their properties are in accord to dry steppe parent rock, climate and SSC conditions: Moderate thick, medium solonized. Properties: $2.6 \%$ of humus, $47.7 \%$ of physical clay, $29.5 \%$ of clay, $0.15 \%$ of $\mathrm{CaCO}_{3}$ (up to $3-10 \%$ at depth of $0,8-1,5 \mathrm{~m}), \mathrm{pH}=7.8$, the exchangeable cations: $\mathrm{Ca}^{2+}-182 \mathrm{mmoL} \mathrm{\textrm {kg } ^ { - 1 }}, \mathrm{Mg}^{2+}-65$ mmoL kg${ }^{-1}, \mathrm{Na}^{+}-34 \mathrm{mmoL} \mathrm{kg}{ }^{-1}$.

Soil was sampled down to the depth of $1 \mathrm{~m}$ from a section wall, deeper-by soil auger, drill cup, diameter 5 $\mathrm{cm}$. In procedure of soil sample preparation the soil was crushed and sifted through openings $2 \mathrm{~mm}$, than mixed with quartz sand in the ratio 1:2 (Endovitsky et al., 2014a; 2014b; Mandzhieva et al., 2014; Zhang et al., 2012; Tertre et al., 2011; Minkina et al., 2013) charged into a glass tube, inner diameter of $3.4 \mathrm{~cm}$, length 100 $\mathrm{cm}$. At the bottom of a tube was mounted draining outlet of excessive solution. The direct allocation of soil solution with ethyl alcohol applied (Mandzhieva et al., 2014; Zhang et al., 2012; Tertre et al., 2011). The extraction volume of soil solution emitted was $20-60 \mathrm{ml}$ from single soil column.

Soil solution analysis as follows (Endovitsky et al., 2014a; 2014b; Visconti and De Paz, 2012; Opfergelt et al., 2014; Kar and Berenjian, 2013; Mari et al., 2014). Moisture-by thermostat $105^{\circ} \mathrm{C}$ method. $\mathrm{pH}$ in thermostat $\left(20 \pm 0,2^{\circ} \mathrm{C}\right)$ by $\mathrm{pH}$-meter using a glass electrode. The carbonate and bicarbonate ions were titrated directly by $0.01 \mathrm{M}$ hydrochloric acid detecting titration, endpoint on color change of indicators phenolphthalein and methyl orange. The chloride ion was determined by argentometric method with potassium chromate. The total content of $\mathrm{Ca}^{2+}$ and $\mathrm{Mg}^{2+}$ was determined with complexometric titration. In another aliquot $\mathrm{Ca}^{2+}$ was determined in complexometric too, $\mathrm{Mg}^{2+}$ calculated by difference. The sulfate was determined with $\mathrm{BaSO}_{4}$ sedimentation method. $\mathrm{Na}^{+}$was determined with flame photometric.

\subsection{Methodic Bases of Calculation of the Main Ions State in Soil Solution}

In former report we formulated methodic bases of calculation of the state of main ions in the soil solution taking into account the ideas of association of ions in soil solutions for the first time and made an 
approach to a quantitative assessment of ions forms in soil solution. The concept and approach are the basis of given research (Endovitsky et al., 2014a; 2014b).

The analytical composition of soil solution is correct at a low concentration of the main ions only. The real measure of soil solution is ion's activity. The analytical composition of the studied soil solution is presented in Table 1.

The real conditions of the main ions in soil solutions were determined taking into account the association of ions and influence of ion activity on physical and chemical properties of solution.

Calculation of free and associated ion form concentration was made according sum of analytical concentration of ion. Methods used: Iteration solving of system of algebraic equations of the material balance of ions, linear interpolation to calculate the values of tabular form of equilibrium constants.

The basis of research is Method of Ionic Pairs (MIP) (Endovitsky et al., 2014a; 2014b): The law of initial concentration, the law of operating masses. The Equation 1-6 of main ions material balance are as follows:

$$
\begin{aligned}
& \sum \mathrm{Ca}^{2+}=\left[\mathrm{Ca}^{2+}\right]+\left[\mathrm{CaCO}_{3}^{\circ}\right]+\left[\mathrm{CaHCO}_{3}^{+}\right]+\left[\mathrm{CaSO}_{4}^{\circ}\right] \\
& \sum \mathrm{Mg}^{2+}=\left[\mathrm{Mg}^{2+}\right]+\left[\mathrm{MgCO}_{3}^{\circ}\right] \\
& +\left[\mathrm{MgHCO}_{3}^{+}\right]+\left[\mathrm{MgSO}_{4}^{\circ}\right] \\
& \sum \mathrm{Na}^{+}=\left[\mathrm{Na}^{+}\right]+\left[\mathrm{NaCO}_{3}^{-}\right]+\left[\mathrm{NaSO}_{4}^{-}\right] \\
& \sum \mathrm{CO}_{3}^{2-}=\left[\mathrm{CO}_{3}^{2-}\right]+\left[\mathrm{CaCO}_{3}^{\circ}\right]+\left[\mathrm{MgCO}_{3}^{\circ}\right]+\left[\mathrm{NaCO}_{3}^{-}\right] \\
& \sum \mathrm{HCO}_{3}^{-}=\left[\mathrm{HCO}_{3}^{-}\right]+\left[\mathrm{CaHCO}_{3}^{+}\right]+\left[\mathrm{MgHCO}_{3}^{+}\right]
\end{aligned}
$$

$\sum \mathrm{SO}_{4}^{2-}=\left[\mathrm{SO}_{4}^{2-}\right]+\left[\mathrm{CaSO}_{4}^{\circ}\right]+\left[\mathrm{MgSO}_{4}^{\circ}\right]+\left[\mathrm{NaSO}_{4}^{-}\right]$

where, in $\left[\mathrm{Ca}^{2+}\right],\left[\mathrm{Mg}^{2+}\right]$-equilibrium concentration of free form of ion, $\left[\mathrm{CaCO}_{3}{ }^{0}\right],\left[\mathrm{MgCO}_{3}{ }^{0}\right]$,-equilibrium concentration of associated forms of ion (ion pair).

The next group of Equation 7-9 -concentration constants of ionic pair dissociation on the law of operating masses, grouped according cations:

$$
\begin{gathered}
K_{\mathrm{CaCO}_{3}}=\frac{\left[\mathrm{Ca}^{2+}\right]\left[\mathrm{CO}_{3}^{2-}\right]}{\left[\mathrm{CaCO}_{3}^{0}\right]} ; K_{\mathrm{CaHCO}_{3}}=\frac{\left[\mathrm{Ca}^{2+}\right]\left[\mathrm{HCO}_{3}^{-}\right]}{\left[\mathrm{CaHCO}_{3}^{+}\right]} \\
; K_{\mathrm{CaSO}_{4}}=\frac{\left[\mathrm{Ca}^{2+}\right]\left[\mathrm{SO}_{4}^{2-}\right]}{\left[\mathrm{CaSO}_{4}^{0}\right]} \\
K_{\mathrm{MgCO}_{3}}=\frac{\left[\mathrm{Mg}^{2+}\right]\left[\mathrm{CO}_{3}^{2-}\right]}{\left[\mathrm{MgCO}_{3}^{0}\right]} ; K_{\mathrm{MgHCO}_{3}}=\frac{\left[\mathrm{Mg}^{2+}\right]\left[\mathrm{HCO}_{3}^{2-}\right]}{\left[\mathrm{MgHCO}_{3}^{+}\right]} \\
K_{\mathrm{MgSO}_{4}}=\frac{\left[\mathrm{Mg}^{2+}\right]\left[\mathrm{SO}_{4}^{2-}\right]}{\left[\mathrm{MgSO}_{4}^{0}\right]} \\
K_{\mathrm{NaCO}_{3}}=\frac{\left[\mathrm{Na}^{+}\right]\left[\mathrm{CO}_{3}^{2-}\right]}{\left[\mathrm{NaCO}_{3}^{-}\right]} ; K_{\mathrm{NaSO}_{4}}=\frac{\left[\mathrm{Na}^{+}\right]\left[\mathrm{SO}_{4}^{2-}\right]}{\left[\mathrm{NaSO}_{4}^{-}\right]}
\end{gathered}
$$

In Equation 1-6 an equilibrium concentration of ionic pairs were replaced by its value using dissociation constants (7-9). The transformed system of material balance of ions was obtained Equation 10-15:

$$
\sum \mathrm{Ca}^{2+}=\left[\mathrm{Ca}^{2+}\right]\left(1+\frac{\left[\mathrm{CO}_{3}^{2-}\right]}{K_{\mathrm{CaCO}_{3}}}+\frac{\left[\mathrm{MgCO}_{3}^{-}\right]}{K_{\mathrm{CaHCO}_{3}}}+\frac{\left[\mathrm{SO}_{4}^{2-}\right]}{K_{\mathrm{CaSO}_{4}}}\right)
$$

$\sum \mathrm{Mg}^{2+}=\left[\mathrm{Mg}^{2+}\right]\left(1+\frac{\left[\mathrm{CO}_{3}^{2-}\right]}{K_{\mathrm{MgCO}_{3}}}+\frac{\left[\mathrm{HCO}_{3}^{-}\right]}{\mathrm{K}_{\mathrm{MgHCO}_{3}}}+\frac{\left[\mathrm{SO}_{4}^{2-}\right]}{\mathrm{K}_{\mathrm{MgSO}_{4}}}\right)$

$\sum \mathrm{Na}^{+}=\left[\mathrm{Na}^{+}\right]\left(1+\frac{\left[\mathrm{CO}_{3}^{2-}\right]}{\mathrm{K}_{\mathrm{NaCO}_{3}}}+\frac{\left[\mathrm{SO}_{4}^{2-}\right]}{\mathrm{K}_{\mathrm{NaSO}_{4}}}\right)$

$\sum \mathrm{CO}_{3}^{2-}=\left[\mathrm{CO}_{3}^{2-}\right]\left(1+\frac{\left[\mathrm{Ca}^{2+}\right]}{K_{\mathrm{CaCO}_{3}}}+\frac{\left[\mathrm{Mg}^{2+}\right]}{K_{\mathrm{MgCO}_{3}}}+\frac{\left[\mathrm{Na}^{+}\right]}{\mathrm{K}_{\mathrm{NaCO}_{3}}}\right)$

$\sum \mathrm{CO}_{3}^{-}=\left[\mathrm{HCO}_{3}^{-}\right]\left(1+\frac{\left[\mathrm{Ca}^{2+}\right]}{\mathrm{K}_{\mathrm{CaHCO}_{3}}}+\frac{\left[\mathrm{Mg}^{2+}\right]}{\mathrm{K}_{\mathrm{MgCO}_{3}}}\right)$

$\sum \mathrm{SO}_{4}^{2-}=\left[\mathrm{SO}_{4}^{2-}\right]\left(1+\frac{\left[\mathrm{Ca}^{2+}\right]}{K_{\mathrm{CaSO}_{4}}}+\frac{\left[\mathrm{Mg}^{2+}\right]}{K_{\mathrm{MgSO}_{4}}}+\frac{\left[\mathrm{Na}^{+}\right]}{\mathrm{K}_{\mathrm{NaSO}_{4}}}\right)$

The concentration dissociation constants in Equation 1015 were recalculated according Davies Equation 16: 


$$
p K=p K^{0}-A \Delta Z^{2}\left(\frac{\sqrt{I}}{1+\sqrt{I}}-0,1 I\right)
$$

where, in K-concentration constant of ion pair dissociation; $\mathrm{K}^{0}$-thermodynamic constant; A-Debye-Huckel constant, 0, 5042 at $20^{\circ} \mathrm{C} ; \Delta \mathrm{z}^{2}$-algebraic sum of ion charges in a second degree; I-ionic strength of soil solution.

Thermodynamic constants of dissociation:

$$
\begin{array}{lll}
p K_{\mathrm{CaCO}_{3}}^{0}=3,2 ; & p K_{\mathrm{CaHCO}_{3}}^{0}=1,26 ; & p K_{\mathrm{CaSO}_{4}}^{0}=2,31 \\
p K_{\mathrm{MgCO}_{3}}^{0}=3,4 ; & p K_{\mathrm{MgHCO}_{3}}^{0}=1,16 ; & p K_{\mathrm{MgSO}_{4}}^{0}=2,36 \\
p K_{\mathrm{NaCO}_{3}}^{0}=1,27 ; & p K_{\mathrm{NaSO}_{4}}^{0}=0,72 &
\end{array}
$$

Formal ionic strength of soil solution on the data of analytical ion concentration Equation 17:

$$
\begin{aligned}
& \mathrm{I}=0,5\left[4\left(\mathrm{Ca}^{2+}\right)+4\left(\mathrm{Mg}^{2+}\right)+\left(\mathrm{Na}^{+}\right)\right. \\
& +4\left(\mathrm{CO}_{3}^{2-}\right)+\left(\mathrm{HCO}_{3}^{-}\right)+ \\
& \left.+4\left(\mathrm{SO}_{4}^{2-}\right)+\left(\mathrm{Cl}^{-}\right)\right], \mathrm{mol} / 1
\end{aligned}
$$

At ionic strength of $0.1 \mathrm{~mol} / \mathrm{l}$ an error of Equation 16 for $\mathrm{pK}$ is less than $3 \%$, at $0.5 \mathrm{~mol} / \mathrm{l}$-less than $8 \%$.

Equilibrium concentration of a free form of ions was used in equation as unknown: $\mathrm{X}_{\mathrm{Ca}}, \mathrm{X}_{\mathrm{Mg}}$. Total value of all ion forms was used as analytical concentration. The system was obtained of six equations with six unknown.

Equilibria concentrations of ion pairs were determined by iteration according equations for dissociation constants (7-9).

According values of equilibrium concentration of all forms of ion was calculated the effective ionic strength of solution Equation 18:

$$
\begin{aligned}
& \mathrm{I}^{*}=0,5\left\{\begin{array}{l}
4\left[\mathrm{Ca}^{2+}\right]+4\left[\mathrm{Mg}^{2+}\right]+\left[\mathrm{Na}^{+}\right] \\
+4\left[\mathrm{CO}_{3}^{2-}\right]+\left[\mathrm{HCO}_{3}^{-}\right]+4\left[\mathrm{SO}_{4}^{2-}\right]+
\end{array}\right. \\
& +\left[\mathrm{CaHCO}_{3}^{+}\right]+\left[\mathrm{MgHCO}_{3}^{+}\right]+\left[\mathrm{NaCO}_{3}^{-}\right] \\
& \left.+\left[\mathrm{NaSO}_{4}^{-}\right]+\left[\mathrm{Cl}^{-}\right)\right\}, \mathrm{mol} / \mathrm{l}
\end{aligned}
$$

Was calculated the concentration dissociation constants (16) and constituted a new system of material balance equations. On the new set of ingredients of system of Equation 10-15 was solved the next iteration approach.

Calculate ion forms in soil solution.

Upon completion of iterative procedure, was determined the quantity of ion free form.
The coefficient of ion association $\gamma_{\mathrm{e}}$ as the ratio of the ions free form to its analytical content Equation 19:

$\gamma_{e}=C_{a s s} / C_{a n}$

where in, $\mathrm{C}_{\mathrm{ass}}$-calculated ion content in the solution taking into account its association with other ions, $\mathrm{C}_{\mathrm{an}}{ }^{-}$ analytical concentration of ion.

\section{RESULTS}

\subsection{Degree of Soil Solution Saturation}

The calculation of ion association of soil solution according to Equation 1-19 for soil solution was presented in details in our previous report (Endovitsky et al., 2014b).

To understand better the processes in soil solution of salted soil, the degree of soil solution saturation is of high importance.

The degree of soil solution saturation was determined for each ion as a ratio of calculated quantity of associated ion and thermodynamic solubility product of corresponding chemical compound. Stages of calculation and equations are given below.

For calculation a thermodynamic chemical compound solubility product for ideal dilute solution was taken into account, $S_{0}$.

The degree of soil solution saturation (first approximation step), $K_{1}$.

Product of the concentrations of ions in case of direct analytical determining Equation 20:

$S_{1}=C_{c} C_{a}$,

where, in $C_{c}$-analytical cation concentration, $C_{a^{-}}$ analytical anion concentration in charged or electrically neutral ion associate Equation 21:

$K_{1}=S_{1} / S_{0}$

The degree of saturation of soil solution (second approximation step), $K_{2}$.

Product of the concentrations of direct analytical determination of ions accounting ion associationproduct of concentration of associated ions, i.e., product of the concentrations of ions of direct analytical determination and estimated association coefficient of each ion Equation 22:

$S_{2}=C_{c} \gamma_{e c} C_{a} \gamma_{e a}$, 
where, in $C_{c}, C_{a}$-see above, $\gamma_{e}$-coefficient of association of cation and anion respectively Equation 23:

$\mathrm{K}_{2}=\mathrm{S}_{2} / \mathrm{S}_{0}$

The degree of saturation of soil solution (third approximation step), $K_{3}$.

The molar coefficient of activity of an ion determined by Debye-Huckel equation, the third approximationin modification of E.A. Guggenheim-C.W. Davies, a linear polarization coefficient 0.1 according to E. Guntelberg (Endovitsky et al., 2014b) Equation 24:

$l g f=-A z^{2}\left(\frac{\sqrt{I^{*}}}{1+\sqrt{I^{*}}}-0,1 I^{*}\right)$

Product of concentrations of direct analytical definition of ions and calculated coefficient of association of each ion and activity coefficient taking into account the effective ionic force $I^{*}$ according ratio (18) Equation 25:

$S_{3}=C_{c} \gamma_{e c} f_{c} C_{a} \gamma_{e a} f_{a}$,

where, in, $C_{c}, C_{a}, \gamma_{e c}, \gamma_{e a}$-see above, f-activity coefficient, respectively, cation and anion Equation 26:
$K_{3}=S_{3} / S_{0}$

\subsection{Degree of Soil Solution Saturation in Landscape}

Research fulfilled show the influence of association of main ions in soil solution on landscape. The origin of landscape differentiation is closely linked to hydrology regime of landscape. The soils of dry steppe are loamyclay composition, have low water resistance. Because of soil properties even at a low level of precipitation appears the lateral differentiation of hydrology regime of landscape. It causes the difference of individual soil salinization, which is reflected in Table $\mathbf{1}$.

On the data of a Table 1 was fulfilled the calculation of association of ions in soil solution of key plots 1324, 1325 according to procedures of methodic bases of calculation of the main ions state in soil solution by Equation 7-18.

Association coefficient $\gamma_{\mathrm{e}}$ was calculated according to ion species as the ratio of calculated amount of ion in a free form to its analytical content in Table 1. The results of calculation are in Table 2 Association coefficient $\gamma_{e}$ is represented in $\%$.

Table1. Ccomposition of the soil solution steppe solonetz, mmol-eq/1

\begin{tabular}{|c|c|c|c|c|c|c|c|c|c|c|}
\hline Layer $(\mathrm{cm})$ & Moisture (\%) & Dry residue (g/l) & $\mathrm{pH}$ & $\mathrm{Ca}^{2+}$ & $\mathrm{Mg}^{2+}$ & $\mathrm{Na}^{+}$ & $\mathrm{CO}_{3}{ }^{2-}$ & $\mathrm{HCO}_{3}{ }^{-}$ & $\mathrm{SO}_{4}^{2-}$ & $\mathrm{Cl}^{-}$ \\
\hline \multicolumn{11}{|c|}{ Key plot 1324} \\
\hline \multicolumn{11}{|c|}{ Solonetz chestnut steppe } \\
\hline $0-10$ & 27.1 & 1.290 & 7.71 & 4.24 & 3.98 & 9.01 & 0.00 & 5.74 & 7.00 & 4.49 \\
\hline $10-27$ & 29.3 & 2.880 & 8.32 & 8.53 & 10.99 & 22.05 & 1.60 & 10.33 & 15.91 & 13.73 \\
\hline $40-50$ & 22.1 & 38.460 & 7.98 & 69.35 & 138.51 & 388.43 & 0.00 & 10.33 & 323.74 & 262.22 \\
\hline $70-80$ & 19.2 & 33.970 & 8.72 & 64.32 & 172.13 & 299.12 & 3.02 & 11.48 & 277.95 & 243.12 \\
\hline \multicolumn{11}{|c|}{ Chestnut solonetzic soil } \\
\hline $0-28$ & 31.4 & 3.30 & 8.10 & 6.83 & 8.57 & 32.71 & 0.00 & 6.84 & 16.41 & 24.86 \\
\hline $60-70$ & 29.8 & 21.89 & 8.20 & 89.35 & 119.32 & 128.21 & 0.00 & 8.61 & 218.42 & 109.85 \\
\hline $90-100$ & 26.9 & 24.53 & 8.35 & 27.20 & 126.61 & 226.35 & 0.42 & 13.72 & 203.85 & 162.17 \\
\hline \multicolumn{11}{|c|}{ Chestnut-dark soil of depression } \\
\hline $0-15$ & 37.7 & 1.30 & 7.60 & 6.92 & 3.56 & 5.43 & 0.00 & 9.33 & 4.53 & 2.05 \\
\hline $40-70$ & 34.2 & 1.20 & 7.80 & 6.98 & 4.53 & 3.87 & 0.00 & 7.92 & 4.11 & 3.35 \\
\hline $90-110$ & 32.6 & 2.62 & 7.90 & 15.20 & 12.36 & 7.66 & 0.00 & 14.42 & 14.53 & 6.27 \\
\hline $130-160$ & 31.3 & 4.30 & 8.40 & 30.21 & 20.21 & 13.24 & 0.95 & 10.84 & 30.54 & 21.33 \\
\hline \multicolumn{11}{|c|}{ Key plot 1325} \\
\hline \multicolumn{11}{|c|}{ Solonetz chestnut meadow } \\
\hline $0-15$ & 32.1 & 4.20 & 8.70 & 8.53 & 14.88 & 38.19 & 2.87 & 11.65 & 16.41 & 30.67 \\
\hline $40-50$ & 33.9 & 5.90 & 8.90 & 10.82 & 19.38 & 59.83 & 3.85 & 10.37 & 14.04 & 61.77 \\
\hline $60-70$ & 33.7 & 41.78 & 9.04 & 48.54 & 218.42 & 403.82 & 4.33 & 18.76 & 248.55 & 399.14 \\
\hline $90-100$ & 25.3 & 51.58 & 8.55 & 29.80 & 226.06 & 578.53 & 0.90 & 7.96 & 363.56 & 461.97 \\
\hline
\end{tabular}


Table 2. Ion association in soil solution, $\%$ of the total ion content

\begin{tabular}{|c|c|c|c|c|c|c|c|}
\hline Layer $(\mathrm{cm})$ & $\mathrm{Ca}^{2+}$ & $\mathrm{Mg}^{2+}$ & $\mathrm{Na}^{+}$ & $\mathrm{CO}_{3}{ }^{2-}$ & $\mathrm{HCO}_{3}^{-}$ & $\mathrm{SO}_{4}^{2-}$ & $\mathrm{Cl}^{-}$ \\
\hline \multicolumn{8}{|c|}{ Key plot 1324} \\
\hline \multicolumn{8}{|c|}{ Solonetz chestnut steppe } \\
\hline $0-10$ & 14.9 & 17.8 & 0.7 & 0.0 & 4.2 & 18.2 & 0 \\
\hline $10-27$ & 26.5 & 28.9 & 2.4 & 0.0 & 6.2 & 24.5 & 0 \\
\hline $40-50$ & 53.8 & 57.3 & 11.9 & 0.0 & 15.5 & 58.6 & 0 \\
\hline $70-80$ & 50.2 & 55.8 & 10.5 & 87.8 & 14.0 & 52.5 & 0 \\
\hline \multicolumn{8}{|c|}{ Chestnut solonetzic soil } \\
\hline $0-28$ & 18.5 & 22.8 & 1.3 & 0.0 & 4.2 & 24.7 & 0 \\
\hline $60-70$ & 45.7 & 53.7 & 7.7 & 0.0 & 5.2 & 51.8 & 0 \\
\hline $90-100$ & 49.5 & 51.2 & 3.2 & 88.2 & 18.1 & 63.2 & 0 \\
\hline \multicolumn{8}{|c|}{ Chestnut-dark soil of depression } \\
\hline $0-15$ & 11.8 & 9.4 & 1.0 & 0.0 & 2.5 & 13.2 & 0 \\
\hline $40-70$ & 12.7 & 10.8 & 0.8 & 0.0 & 2.2 & 11.8 & 0 \\
\hline $90-110$ & 19.5 & 15.6 & 1.2 & 0.0 & 8.4 & 13.2 & 0 \\
\hline $130-160$ & 38.2 & 43.3 & 2.5 & 82.2 & 15.8 & 22.7 & 0 \\
\hline \multicolumn{8}{|c|}{ Key plot 1325} \\
\hline \multicolumn{8}{|c|}{ Solonetz chestnut meadow } \\
\hline $0-15$ & 29.1 & 34.5 & 3.6 & 68.7 & 3.8 & 19.9 & 0 \\
\hline $40-50$ & 31.1 & 35.3 & 3.9 & 73.8 & 4.7 & 42.2 & 0 \\
\hline $60-70$ & 43.2 & 48.8 & 6.6 & 88.1 & 6.7 & 57.2 & 0 \\
\hline $90-100$ & 40.1 & 49.9 & 5.8 & 92.7 & 22.3 & 62.7 & 0 \\
\hline
\end{tabular}

\section{DISCUSSION}

\subsection{Association of Main Ions in Soil Solution of Landscape}

As a result of calculations the different levels of soil solution saturation are revealed. The results are in a close dependence to what laws and ingredients of calculation are included into the calculation procedure.

The calculation of soil solution's super saturation degree $K_{1}$ of soils of key plots was made as the mathematical product of analytical electrically charged and neutral ionic pairs $S_{1}$ relating to thermodynamic solubility product $S_{0}$, Equation 2.20, 2.21. It was found that a substantial part of the studied soil solutions are supersaturated. Especially in respect of $\mathrm{CaCO}_{3}$, wherein: Substantially -2.5 times, much $-10-20$ times and very strongly-100 times.

Was calculated the real equilibrium concentration of various forms of ion in soil solution. Calculation results show that depending on concentration and composition of soil solution in form of ionic pairs are: $11.8-53.8 \%$ of $\mathrm{Ca}^{2+} ; 9.4-57.3 \%$ of $\mathrm{Mg}^{2+} ; 0.7-11.9 \%$ of $\mathrm{Na}^{+} ; 2.2-22.3 \%$ of $\mathrm{HCO}_{3}{ }^{-}, 11.8-62.7 \%$ of $\mathrm{SO}_{4}{ }^{2-}$. The ion $\mathrm{CO}_{3}{ }^{2-}$ is associated in the most degree, the share of ions in associated form is up to $92.7 \%$.

Ion association process explains an excess ions concentration in soil solution in comparison to ion thermodynamic solubility product for different modeling systems (Endovitsky et al., 2014a; 2014b; Izgorodina, 2011; Izgorodina et al., 2014; Kalinichenko, 2012a; Luo et al., 2013; Zhang et al., 2012), ion pair association in supercritical water and other conditions (Sushkova et al., 2013; Saito, 2013), to develop the methods of computer modeling of ion pair formation in electrolyte, ion pair as a simulation of hybrid excitations in solution (Raiteri et al., 2012; Maiti and Rogers, 2011; Lui et al., 2011; Farnum et al., 2011; Plugatyr et al., 2011; Kielpinski, 2013). In the recent years the imporved methods of direct ion pair study are used (Westerlund et al., 2011; BešterRogač et al., 2011; Wang et al., 2014; Shatti et al., 2011; Zhang et al., 2012; Tertre et al., 2011; Wiatrak, 2014; Jiang et al., 2012; Saito, 2013; Minkina et al., 2013; Minkina et al., 2012; Sushkova et al., 2013; Kalinichenko et al., 2011; 2012a; 2012b; 2014; Mandzhieva et al., 2014; El Marazky et al., 2011).

The association of ions varies in soil layers. An increase of soil solution salinity amplifies the ions association. The association of ions in soil solution varies in landscape too on the level of components of soil complex of SSC. SSC components for most common soil complex of dry steppe are represented on key plot 1324.

The key plot 1325 has a feature. It is laterally separated from the key plot 1324 to reveal the special properties of solonetz chestnut meadow soil. This soil is less common than soils of key plot 1324. It appears only in local depressions of saline plain of chestnut soils area. However, the knowledge of the soils of this kind is vital 
because they represent the most unfavorable component of soil cover in terms of plant grow condition. In the soil solution of solonetz chestnut meadow soil of key plot 1325 there is a high value of $\mathrm{pH}$, soda is presented. Therefore, according to the calculations, in this soil a significant part of ions, especially $\mathrm{CO}_{3}{ }^{2-}$, are in the state of association.

The calculation is fulfilled of soil solutions saturation degree of soils of key plots according to product of ion analytical content accounting association of ions- $K_{2} . K_{2}$ is a ratio of analytical content of ions in the corresponding form of ion pairs or molecules and a thermodynamic solubility product $S_{0}$ taking into account ion association. The product of analytical content of ions in the ion pair or a molecule was multiplied by estimated coefficient of association of ion, which constitutes the associate. Equation 22, 23.

Calculation shows that, given the association of ions according to Equation 19, 22, 23, the calculated degree of saturation of the soil solution $K_{2}$ is significantly less compared to the first embodiment of saturation calculation $K_{1}$, made only on analytical concentrations of ions. This is noticeable for $\mathrm{CaCO}_{3}$. The degree of super saturation $K_{2}$ is about 1 , for some samples $K_{2}=2-3$. Few samples have $K_{2}=5-10$.

Equation 24 is the third approximation of the DebyeHuckel equation amended EA Guggenheim-C.W. Davies with linear polarization coefficient of E. Guntelberg. Using Equation 24 on the data of Table 1 was calculated the ion activity coefficient $f$. The data were pretreated in iterative process according Equation 7-18.

The third embodiment of saturation calculation is $K_{3}$. The calculation of soil solutions saturation degree $K_{3}$ of key plots is a product of analytical content of ion pairs in ratio to thermodynamic solubility product $S_{0}$, given the association of ion and ion activity. The product of the analytical content of ions constituting ion pair, molecule, was multiplied by calculated ion association coefficient $\gamma_{e}$ and activity coefficient $\mathrm{f}$ according Equation 25 and 26.

Calculations show that in the third embodiment, when the association and activity of the ions were taken into account, the calculated soil solution saturation degree $K_{3}$ was significantly lower compared to other calculation results. The special difference was from the first embodiment of soil solution oversaturation calculation, in which were considered only the analytical concentrations of ions according to $K_{1}$ procedure. Using $K_{3}$ gave the significant difference compared to second embodiment of calculation, which took into account the association of ions $K_{2}$.
There is a fundamental difference between the $K_{3}$ from the previous versions $K_{1}, K_{2}$. Considering analytical concentrations $K_{1}$ only, the soil solution super saturation, especially regarding $\mathrm{CaCO}_{3}$, was high. Given the association of ions the estimated soil solution super saturation calculated $K_{2}$ was decreased compared to $K_{1}$. But at the same time, the general nature of the calculation results do not changed-in most cases the calculated soil solution super saturation occurred. At the same time, given the association of ions, ions activity, in most cases the calculated soil solution super saturation $K_{3}$ was not revealed, even for $\mathrm{CaCO}_{3}$. Though it is often believed that the natural water and soil solutions are supersaturated with $\mathrm{CaCO}_{3}$ (Endovitsky et al., 2014a; 2014b).

A super saturation of the soil solution according to the value $K_{3}$ appears only at key plot 1325 in solonetz chestnut meadow soil, $K_{3} \approx 2-5$. This is due to the organic matter in soil solution, which content in soil is relatively larger than in other soils. In this very specific soil object an organic matter contained in the soil solution plays its own role in association of ions, in particular, forms the complexes of ions with organic matter. In this article the formation of organic complexes we do not consider. In some details a super saturation phenomenon in this soil were considered earlier. The formation of organic complexes in the soil solution will be the subject of a future special message too.

On the basis of theoretical generalization of soil solution thermodynamics, studies and calculations fulfilled it can be argued that the use of association of ions and ion activity calculating the soil solution's saturation degree of various compounds provides a fundamentally new picture of migration and accumulation of chemicals in soils and landscapes, especially regarding $\mathrm{CaCO}_{3}$.

\subsection{Influence of Association of Main Ions in Soil Solution on Landscape}

The layers of individual soil sections and soils of landscape are interacting.

The state of carbonate calcium system of soil solution in individual small part of soil volume can be characterized at exact time. In addition, the calculation explains the metamorphisation of soil solution in time and through the soil continuum under water salt mass transfer.

In landscape in circumstances of soil salinity the soil continuum is characterized by high ions mobility in soil solution. Geochemical barriers of landscape at the soil bottom and between soils are weak. The salts migrate 
through soil continuum freely and constantly influence the soil evolution. On these causes the origin of SSC is stable and its forecast on the reason of agriculture is unfavorable. The nature watering of chestnut soil complex in insufficient for plat grow. But if the soil moisture will be increased this will be not positive for soil's fertility. Under higher watering the migration of salts through soil continuum will increased as well and complex of soils as a whole will be under more negative influence of salts. The cause is vertical and lateral watersalt transfer, metamofization and second accumulation of salts in soil. It is in accord to proposed thermodynamic model of macro processes of salt saturation in soil solution. The model shows that salt transfer in complex of chestnut soils is significant feature of the object of research. So the prediction of chestnut soil complex evolution in conditions of salinization is unfavorable. To maintain soils there is need to correct hydrological regime of landscape, maintain the proper soil solution equilibrium, regulate total and partial salt content, apply addition water to soil in proper quantities and in proper part of soil continuum without actual improper consequences of irrigation and other soil practices. It is important because of soil degradation, which is probable under known conventional methods of land use (International..., Irrigation...). Calculations fulfilled show that soil degradation scenario taking into account the laws of association of ions in soil solution and spatial differentiation of soils is much more probable and dangerous than it was assessed before.

\section{CONCLUSION}

Calculations fulfilled show the dependence of soil solution composition on association of ions and ions activity. On the ideas of ions association in soil solution there is a possibility of a new glance on processes in soil solution, soil and landscape (Endovitsky et al., 2014a; 2014b; Visconti and De Paz, 2012; Minkina et al., 2014). The $\mathrm{CaCO}_{3}$ sedimentation in saline soil occurs at much higher concentration of ions $\mathrm{Ca}^{2+}$ and $\mathrm{CO}_{3}{ }^{2-}$ in soil solution than it was considered previously. The significantly high mobility of $\mathrm{CaCO}_{3}$ in soil and landscape is probable, other ions too. The salinity of soils in landscape is laterally differentiated. Some soils of soil complex have salinity less then the salinity of other soils. It is caused by excessive moistening. In this soil a soil solution is extremely mobile. Thus salts form this soil are not only leached downward, but can be supplied to other soils of complex.
The shortcoming of research fulfilled is the calculation of ions behavior in soil solutions in the layers of soil sections of landscape. It is obvious that these section are influencing one another and there is need to characterize the origin and level of coordination of different soils of landscape and to use this phenomenon properly for maintenance of soil complex.

The knowledge of association of ions in soil solution matters for modern evolution of salted soils understanding, proper use of these soils.

For better and stable management of saline soils of chestnut laterally differentiated soil complex of dry steppe there is need to understand better the origin of vertical and lateral water salt transfer, metamofization and second accumulation of salts in different soils of soil complex. On the other hand, it is important to find the ways how to reduce mobility of ions of saline soil's landscape and obtain more stable geochemical barriers in landscape and soil which will prevent or at least reduce a negative influence of salts on the SSC and soil productivity.

The landscape productivity is important not from the point of view of food production. Also it is important form the point of biosphere productivity as its main function determining biosphere stability and a possibility of mankind survival under soils degradation and climate change. The landscape productivity can be increased on the base of knowledge of association of ions, ions activity, SSC of saline landscape properties, new understanding of geochemical barriers, ecological functions of soil and water-salt transfer correction by method of Biogeo system technique and it is the goal of future research. It will help to improve the rain fed and irrigational agriculture (Kalinichenko et al., 2011; 2012a; 2012b; 2014).

\section{ACKNOWLEDGMENT}

This research was supported by projects of Ministry of Education and Science of Russia, no. 5.885.2014/K, Russian Foundation for Basic Research, no. 14-05-00586_a.

\section{REFERENCES}

Amakor, X.N., A.R. Jacobson and G.E. Cardon, 2013. Improving estimates of soil salinity from saturation paste extracts in calcareous soils. Soil Sci. Soc. Am. J., 77: 792-799. DOI: 10.2136/sssaj2012.0235

Bešter-Rogač, M., A. Stoppa, J. Hunger, G. Hefter and R. Buchner et al., 2011. Association of ionic liquids in solution: A combined dielectric and conductivity study of $[\mathrm{bmim}][\mathrm{Cl}]$ in water and in acetonitrile. Phys. Chem. Chem. Phys., 13: 17588-17598. DOI: 10.1039/C1CP21371G 
Dave, D. and A.K. Dikshit, 2011. Effect of different exogeneous compounds on biosorption of endosulfan. Am. J. Environ. Sci., 7: 224-236. DOI: 10.3844/ajessp.2011.224.236

El Marazky, M.S.A., F.S. Mohammad and H.M. AlGhobari, 2011. Evaluation of soil moisture sensors under intelligent irrigation systems for economical crops in arid regions. Am. J. Agric. Biol. Sci., 6: 287-300. DOI: 10.3844/ajabssp.2011.287.300

Endovitsky, A.P., V.P. Kalinitchenko and T.M Minkina, 2014a. State of led and cadmium in chernozem after apply of phosphogypsum. Soil Sci., 3: 340-350. DOI: 10.7868/S0032180X14030058

Endovitsky, A.P., T.M. Minkina, V.P. Kalinichenko, A.A. Batukaev and S.N. Sushkova et al., 2014b. The association of ions in the soil solution of saline soils. Am. J. Agric. Biol. Sci., 9: 238-244. DOI: 10.3844/ajabssp.2014.238.244

Farnum, B.H., J.M. Gardner, A. Marton, A.A. NarducciSarjeant and G.J. Meyer et al., 2011. Influence of ion pairing on the oxidation of iodide by MLCT excited states. Dalton Trans., 40: 3830-3838. DOI: 10.1039/C0DT01447H

Hunenberger, P. and M. Reif, 2011. Single-ion Solvation. In: Experimental and Theoretical Approaches to Elusive Thermodynamic Quantities. Jonathan H. (Ed.)., Cambridge, Royal Society of Chemistry, Science Park, Milton Road, UK, ISBN10: 1847551874.

Izgorodina, E.I., 2011. Towards large-scale, fully ab initio calculations of ionic liquids. Phys. Chem. Chem. Phys., 13: 4189-4207. DOI: 10.1039/C0CP02315A

Izgorodina, E.I., D. Golze, R. Maganti, V. Armel and M. Taige et al., 2014. Importance of dispersion forces for prediction of thermodynamic and transport properties of some common ionic liquids. Phys. Chem. Chem. Phys., Adv. Article, 16: 7209-7221. DOI: $10.1039 / \mathrm{C} 3 \mathrm{CP} 53035 \mathrm{C}$

Jiang, C.L., J.M. Séquaris, H. Vereecken and E. Klumpp, 2012. Effects of inorganic and organic anions on the stability of illite and quartz soil colloids in $\mathrm{Na}-, \mathrm{Ca}-$ and mixed $\mathrm{Na}-\mathrm{Ca}$ systems. Colloids Surfaces A: Physicochem. Eng. Aspects, 415: 134-141. DOI: 10.1016/j.colsurfa.2012.10.007

Kalinichenko, V.P., V.K. Sharshak, O.S. Bezuglova, E.P. Ladan and L.P. Il'ina et al., 2011. Changes in the soils of solonetzic associations in 30 years after their reclamation with the use of moldboard plowing, deep tillage with a three-tier plow and deep rotary tillage. Eurasian Soil Sci., 44: 927-938. DOI: 10.1134/S1064229311080060
Kalinichenko, V.P., M.M. Kodzoev, A.M. Tochiev, B.B. Mamilov and M.A. Bazgiev et al., 2012a. Soil ecosystem management in birdlime utilization. Europ., 25: 1042-1049.

Kalinichenko, V.P., V.K. Sharshak, V.E. Zinchenko, A.A. Zarmaev and L.P. Il'ina et al., 2012b. Longterm impact of rotary method of soil mechanical treatment on soil properties. Eur. Res., 31: 16491656.

Kalinichenko, V.P., V.K. Sharhak, S.F. Mironchenko, V.V. Chernenko and E.B. Kippel et al., 2014. Vhange of properties of soils of solonetzic complex after 30 years of reclamative processing. Soil Sci., 4: 490-506. DOI: 10.7868/S0032180X14040029

Kar, S.Z. and A. Berenjian, 2013. Soil formation by ecological factors: Critical review. Am. J. Agric. Biol. Sci., 8: 114-116. DOI: 10.3844/ajabssp.2013.114.116

Kielpinski, D., 2013. Viewpoint: Ion pair simulates hybrid excitations. Physics, 6: 112-112. DOI: 10.1103/Physics.6.112

Lui, M.Y., L. Crowhurst, J.P. Hallett, P.A. Hunt and T. Welton et al., 2011. Salts dissolved in salts: Ionic liquid mixtures. Chem. Sci., 2: 1491-1496. DOI: 10.1039/C1SC00227A

Luo, Y., W. Jiang, H. Yu, A.D. MacKerell and B. Roux et al., 2013. Simulation study of ion pairing in concentrated aqueous salt solutions with a polarizable force field. Faraday Discus., 160: 135149. DOI: $10.1039 / \mathrm{C} 2$ FD20068F

Maiti, A. and R.D. Rogers, 2011. A correlation-based predictor for pair-association in ionic liquids. Phys. Chem. Chem. Phys., 13: 12138-12145. DOI: 10.1039/C1CP21018A

Mandzhieva, S.S., T.M. Minkina, S.N. Sushkova, G.V. Motuzova and V.A. Chapligin et al., 2014. The group composition of metal compounds in soil as an index of soil ecological state. Am. J. Agric. Biol. Sci., 9: 19-24. DOI: 10.3844/ajabssp.2014.19.24

Mari, I.A., C. Ji, F.A. Chandio, C. Arslan and F. Ahmad et al., 2014. Rheological properties of paddy soil under various pressure, water content and tool shapes. Am. J. Agric. Biol. Sci., 9: 25-32. DOI: 10.3844/ajabssp.2014.25.32

Minkina, T.M., D.L. Pinskii, S.S. Mandzhieva, U.A. Fedorov and T.V. Bauer et al., 2014. Adsorption features of $\mathrm{Cu}(\mathrm{II}), \mathrm{Pb}$ (II) and $\mathrm{Zn}$ (II) by an Ordinary Chernozem from Nitrate, Chloride, Acetate and Sulfate Solutions. Eurasian Soil Sci., 47: 10-17. DOI: 10.1134/S1064229313110069 
Minkina, T.M., G.V. Motuzova, S.S. Mandzhieva and O.G. Nazarenko, 2012. Ecological resistance of the soil-plant system to contamination by heavy metals. J. Geochem. Explorat., 123: 33-40. DOI: 10.1016/j.gexplo.2012.08.021

Mary, M.Y. and K.A. Carol, 2014. Methods of Group Exercise Instruction. 3rd Edn., Human Kinetics, Illustrated, ISBN-10: 145042189X, pp: 440.

Minkina, T.M., S.N. Sushkova, S.S. Mandzhieva, I.G. Tjurina and O.V. Filonova et al., 2013. Monitoring researches of the benzo[a]pyrene content in soils under the influence of the technogenic zone. Middle-East J. Sci. Res., 17: 44-49. DOI: 10.5829/idosi.mejsr.2013.17.01.11241

Opfergelt, S., K.W. Burton, R.B. Georg, A.J. West and A.N. Halliday et al., 2014. Magnesium retention on the soil exchange complex controlling $\mathrm{Mg}$ isotope variations in soils, soil solutions and vegetation in volcanic soils, Iceland. Geochim. Cosmochimica Acta, 125: 110-130. DOI: 10.1016/j.gca.2013.09.036

Plugatyr, A., R.A. Carvajal-Ortiz and I.M. Svishchev, 2011. Ion-Pair Association Constant for $\mathrm{LiOH}$ in Supercritical Water. J. Chem. Eng. Data, 56: 36373642. DOI: $10.1021 /$ je2004808

Raiteri, P., R. Demichelis, J.D. Gale, M. Kellermeier and T.R. Walsh et al., 2012. Exploring the influence of organic species on pre- and post-nucleation calcium carbonate. Faraday Discuss., 159: 61-85. DOI: 10.1039/C2FD20052J

Saito, C.H., 2013. Environmental education and biodiversity concern: Beyond the ecological literacy. Am. J. Agric. Biol. Sci., 8: 12-27. DOI: 10.3844/ajabssp.2013.12.27

Shatti, L.A.A., H.M. Marafie and A.F. Shoukry, 2011. Plastic membrane electrodes of coated wire type for micro determination of quininium cation in pharmaceutical tablets. Am. J. Applied Sci., 8: 116123. DOI: 10.3844/ajassp.2011.116.123

Stoyanov, E.S., I.V. Stoyanova and C.A. Reed, 2011. The unique nature of $\mathrm{H}+$ in water. Chem. Sci., 2: 462-472. DOI: $10.1039 / \mathrm{COSC} 00415 \mathrm{D}$
Sushkova, S.N., T.M. Minkina, S.S. Mandzhieva and I.G. Tjurina, 2013. Elaboration and approbation of methods for benzo[a]pyrene extraction from soils for monitoring of the ecological state in technogenic landscapes. World Applied Sci. J., 25: 1432-1437.

Tertre, E., D. Prêt and E. Ferrage, 2011. Influence of the ionic strength and solid/solution ratio on $\mathrm{Ca}(\mathrm{II})$-for$\mathrm{Na}+$ exchange on montmorillonite. Part 1: Chemical measurements, thermodynamic modeling and potential implications for trace elements geochemistry. J. Colloid Interface Sci., 353: 248256. DOI: 10.1016/j.jcis.2010.09.039

Visconti, F. and J.M. De Paz, 2012. Prediction of the soil saturated paste extract salinity from extractable ions, cation exchange capacity and anion exclusion. Soil Res., 50: 536-550. DOI: 10.1071/SR12197

Wang, T., J. Liu, H. Sun, L. Chen and Y. Bi et al., 2014. Exploring the mechanism of ion-pair recognition by new calix[4]pyrrole bis-phosphonate receptors: Insights from quantum mechanics study. Res. Adv., 4: 1864-1873. DOI: 10.1039/C3RA44380A

Westerlund, F., J. Elm, J. Lykkebo, N. Carlsson and B.W. Laursen et al., 2011. Direct probing of ion pair formation using a symmetric triangulenium dye. Photochem. Photobiol. Sci., 10: 1963-1973. DOI: 10.1039/C1PP05253E

Wiatrak, P., 2014. Evaluation of nitrogen application methods and rates with nutrisphere-n on soil nitratenitrogen in southeastern coastal plains. Am. J. Agric. Biol. Sci., 9: 64-71. DOI: 10.3844/ajabssp.2014.64.71

Zhang, L., J.E. Petersen, W. Zhang, Y. Chen and Q. Huang et al., 2012. Interactions of 14C-labeled multi-walled carbon nanotubes with soil minerals in water. Environ. Pollut., 166: 75-81. DOI: 10.1016/j.envpol.2012.03.008 